\title{
Effect of Glucose on Thermal Injury of Yeast that may Define the Maximum Temperature of Growth
}

\author{
By A. N. HAGLER AND M. J. LEWIS \\ Department of Food Science and Technology, \\ University of California, Davis, California 95616, U.S.A.
}

(Received 30 April I973; revised 9 July 1973)

\begin{abstract}
SUMMAR Y
Anaerobically grown yeast, suspended in glucose solution, leaked cell contents non-selectively. The rate of leakage increased with temperature but reached a maximum rate close to the maximum temperature of growth $\left(T_{\max }\right)$ of the yeast. The total leakage induced by glucose was much greater above $T_{\max }$ than below it, because above $T_{\max }$ the yeast lost the ability to take up released material. The rate of uptake of ${ }^{14} \mathrm{C}$-labelled amino acids was also substantially slowed above $T_{\max }$. Yeast heat-stressed in the presence of glucose lost the ability to establish and maintain a concentration gradient of sorbose, and simultaneously ATPase activity could be measured, all characteristics of yeast with a ruptured cytoplasmic membrane. These effects were uniquely caused by utilizable sugars, were essentially independent of sugar concentration and could be partially inhibited by $\mathrm{Ca}^{2+}$ or inhibitors that prevent sugar utilization. Yeast heated above $T_{\max }$ in water suspension was essentially undamaged as determined by the tests used, but if glucose was subsequently added below $T_{\max }$ an effect of heat damage could be demonstrated. We conclude that one factor that determines the $T_{\max }$ of a yeast is the temperature sensitivity of the cytoplasmic membrane in the presence of the utilizable sugar of the growth medium.
\end{abstract}

\section{INTRODUCTION}

Yeasts have a maximum growth temperature $\left(T_{\max }\right)$ in the range 18 to $50{ }^{\circ} \mathrm{C}$ which can be defined experimentally to within one degree; the response to temperature is therefore precise. Characteristic changes in yeast that correspond closely to $T_{\max }$ have not been identified.

A yeast grown at the same rate at different temperatures had a different content of some enzymes (Jones \& Hough, I970). The $T_{\max }$ of a psychrophilic Cryptococcus sp., a Candida sp. and Candida gelida was attributed to the heat-sensitivity of certain enzymes of the tricarboxylic acid cycle (Hagen \& Rose, 1962; Evison \& Rose, 1965; Sinclair \& Stokes. 1965; Grant, Sinclair \& Nash, I968). At temperatures well in excess of $T_{\max }, C$. gelida was found to have relatively heat-sensitive amino acyl-tRNA synthetases and ribosomes (Nash, Grant \& Sinclair, 1969; Nash \& Grant, I969). Multiple heat-induced lesions may account for the temperature sensitivity of these yeasts (Nash \& Grant, 1969). Van Uden. Abranches \& Cabeca-Silva (I968) determined the specific death rate of ten yeasts $\left(T_{\max }\right.$ 22 to $49^{\circ} \mathrm{C}$ ) in aqueous suspensions at different temperatures. A poor correlation was found between yeast death rate and $T_{\max }$ except for yeasts with a particularly high $T_{\max }$.

Brock (1967) suggested that the cytoplasmic membrane is the thermostable structure which allows thermophiles to grow at high temperature. This was supported by a study of proto- 
plasts of thermophilic and mesophilic bacteria (Ray \& Brock, I97I) and a mycoplasma (Belly \& Brock, 1972). Yeast protoplasts were more heat stable if prepared from yeast grown at $30^{\circ} \mathrm{C}$ rather than at $15{ }^{\circ} \mathrm{C}$, and this could be correlated with some properties of the yeast membrane (Diamond \& Rose, I970). Nash \& Sinclair (1968) implicated membrane damage in thermal injury of Candida nivalis but long periods of incubation in water suspension were required above $T_{\max }$ to demonstrate significant thermal injury as judged by leakage of contents and loss of viability. Though the cytoplasmic membrane may have a part to play, it has not been ascribed a major role in determining the temperature dependence of yeasts (Stokes, I97I).

In our work we have used primarily mesophilic yeasts and have replaced the water or buffer suspension systems used by other workers with glucose solution, because growth is usually determined in media containing utilizable sugar and because we have previously shown that glucose can induce leakage of yeast contents by an effect on the cytoplasmic membrane (Lewis \& Stephanopoulos, 1967). This leakage is irreversible under some conditions (Lewis \& Phaff, I965). Indge (I968) reported lysis of yeast protoplasts by glucose. We now find that there is a close correlation between (i) the rate, extent and reversibility of glucose-induced leakage of yeast contents, and (ii) the rate of amino-acid uptake in the presence of glucose, with the $T_{\max }$ of the yeast under study, and that this is related to damage to the cytoplasmic membrane.

\section{METHODS}

Yeast strains. Four yeast strains were selected: Leucosporidium stokesii University of California culture number $69-3$, isolated from antarctic snow, $T_{\max } 20{ }^{\circ} \mathrm{C}$; Saccharomyces carlsbergensis $67-80$, a commercial lager yeast, $T_{\max } 34{ }^{\circ} \mathrm{C}$; Saccharomyces cerevisiae $62-5$, a commercial baker's yeast, $T_{\max } 40^{\circ} \mathrm{C}$; Kluyveromyces fragilis $6 \mathrm{I}-293$, isolated from a California orchard, $T_{\max } 45^{\circ} \mathrm{C}$. The yeasts were grown on a rich semi-defined medium ( $1.5 \mathrm{l})$ containing glucose, with occasional stirring for 3 days (Lewis \& Phaff, I964). Leucosporidium stokesii was grown at $13{ }^{\circ} \mathrm{C}$, the other yeasts at $25^{\circ} \mathrm{C}$. Kluyveromyces fragilis was also grown at $37^{\circ} \mathrm{C}$ as indicated. The yeasts were harvested, washed three times in distilled water at their growth temperature and used immediately. In use, the yeasts were suspended in $50 \mathrm{ml}$ of water or glucose solution (usually $5 \%, w / v$ ) either with or without $\mathrm{Ca}^{2+}\left(\mathrm{IO}^{-2} \mathrm{M}\right)$ to a final concentration of $10 \mathrm{mg}$ dry $\mathrm{wt} / \mathrm{ml}$. The solutions were adjusted to the test temperature before addition of the yeast suspension (I0 \%, v/v, of final volume). Samples $(5 \mathrm{ml})$ were taken at suitable time intervals and centrifuged to remove yeast. Extracts of yeast, made in a boiling water bath for $20 \mathrm{~min}$, were cooled, centrifuged and diluted to known volume.

Analyses. Phosphate was measured by the method of Fiske \& SubbaRow (I925) and reported as inorganic phosphorus $\left(\mathrm{P}_{\mathrm{i}}\right)$. Amino acids were determined by the ninhydrin method of Moore \& Stein (1954). Ultra-violet absorbing substances were determined at $260 \mathrm{~nm}$ in a Beckman DB spectrophotometer. ATPase was determined as described by Ohwaki \& Lewis (1971). The sorbose-retention experiments were conducted as described by Cirillo, Harsch \& Lampen (1964) and used yeast freed of glucose by saline washing. Intracellular sorbose was determined by the method by Dische \& Devi (I960) on hot-water extracts of yeast washed four times with saline at $0{ }^{\circ} \mathrm{C}$ or with uranyl nitrate solution (Cirillo \& Wilkins, I964). Presumed cell death was determined by a simple methylene-blue staining technique, the results of which are reported to the nearest $5 \%$. Uptake of uniformly ${ }^{14} \mathrm{C}$-labelled L-amino acids was determined as previously described (Lewis \& Stephanopoulos, 1967). 
Table I. Effect of sugars on release of intracellular phosphate by Saccharomyces carlsbergensis $67-80$ at $44{ }^{\circ} \mathrm{C}$

The yeast, $10 \mathrm{mg}$ dry $w \mathrm{t} / \mathrm{ml}$, was suspended in water or sugar solution with or without $\mathrm{Ca}^{2+}\left(10^{-2} \mathrm{M}\right)$ at $44{ }^{\circ} \mathrm{C}$. Phosphate release, reported as $\mu \mathrm{g} / \mathrm{ml}$ inorganic phosphorus $\left(\mathrm{P}_{\mathrm{i}}\right)$, was measured after $\mathrm{I} h$. The yeast was adapted to utilize maltose or galactose by growth on that sugar using an inoculum pre-adapted by growth on that sugar plus $0.1 \%(w / v)$ glucose.

Yeast suspended in

Water

Glucose

Glucose $+\mathrm{Ca}^{2+}$

Sucrose

Sucrose $+\mathrm{Ca}^{2+}$

Maltose

Maltose, adapted

Maltose, adapted, $+\mathrm{Ca}^{2+}$

Galactose

Galactose, adapted

Lactose

Glucose

Glucose + 2,4-dinitrophenol

Glucose + sodium azide

Glucose + sodium fluoride

Glucose + sodium iodoacetate
Sugar concentration $(\%, w / v)$

\begin{tabular}{|c|c|c|c|c|c|c|}
\hline 0 & 0.2 & 0.4 & 0.8 & $2 \cdot 0$ & 5.0 & 10.0 \\
\hline
\end{tabular}

$\begin{array}{rrrrrrr}2 \cdot 5 & - & - & - & - & - & - \\ - & 25 \cdot 0 & 37 \cdot 0 & 38 \cdot 0 & 37 \cdot 0 & 35 \cdot 0 & 35 \cdot 0 \\ - & 4 \cdot 8 & 5 \cdot 2 & 6 \cdot 0 & 6 \cdot 5 & 6 \cdot 0 & 7 \cdot 0 \\ - & 28 \cdot 0 & 34 \cdot 0 & 37 \cdot 0 & 38 \cdot 0 & 38 \cdot 0 & 37 \cdot 0 \\ - & - & 6 \cdot 2 & - & 6 \cdot 0 & - & 8 \cdot 0 \\ - & 2 \cdot 7 & 3 \cdot 0 & 4 \cdot 8 & 4 \cdot 5 & 5 \cdot 0 & 4 \cdot 8 \\ - & - & 30 \cdot 0 & - & 29 \cdot 0 & - & 32 \cdot 0 \\ - & - & - & - & 5 \cdot 2 & - & 6 \cdot 4 \\ - & 2 \cdot 2 & 3 \cdot 6 & 4 \cdot 1 & 3 \cdot 6 & 3 \cdot 4 & 3 \cdot 2 \\ - & - & 28 \cdot 0 & - & 31 \cdot 0 & - & 28 \cdot 0 \\ - & - & 4 \cdot 2 & - & 7 \cdot 6 & - & 8 \cdot 0 \\ - & - & - & - & - & 41 \cdot 0 & - \\ - & - & - & - & - & 46 \cdot 0 & - \\ - & - & - & - & - & 48 \cdot 0 & - \\ - & - & - & - & - & 29 \cdot 0 & - \\ - & - & - & - & - & 18 \cdot 0 & - \\ - & - & - & - & - & 10 \cdot 0 & - \\ - & - & - & - & - & 8 \cdot 0 & - \\ - & - & - & - & - & 18 \cdot 0 & - \\ - & - & - & - & - & 15 \cdot 0 & -\end{array}$

RESULTS

\section{Effect of sugars on a yeast}

When Saccharomyces carlsbergensis $67-80\left(T_{\max } 34^{\circ} \mathrm{C}\right)$ was suspended in water at $44^{\circ} \mathrm{C}$ there was little release of yeast contents, but in glucose solution at $44^{\circ} \mathrm{C}$ leakage of contents was rapid and extensive. In $3 \mathrm{~h}$ the yeast released almost its entire content of hot-water extractable $\alpha$-amino nitrogen, u.v.-absorbing substances and phosphate. Calcium ions $\left(\mathrm{IO}^{-2} \mathrm{M}\right)$ temporarily protected the yeast against such glucose-induced leakage. In the presence of glucose at $30{ }^{\circ} \mathrm{C}$ leakage was much less than at $44{ }^{\circ} \mathrm{C}$ and was characterized by resorption of the released material (Lewis \& Phaff, I964), except u.v.-absorbing substances (Lee \& Lewis, 1968). Rapid leakage at $44{ }^{\circ} \mathrm{C}$ occurred when yeast was suspended in utilizable sugar. Thus maltose and galactose caused leakage only when yeast was adapted to ferment these sugars (Table I). The glucose-induced leakage at $44{ }^{\circ} \mathrm{C}$ was essentially independent of glucose concentration in the range 0.2 to $10 \% \mathrm{w} / \mathrm{v} ; 2,4$-dinitrophenol slightly increased glucose-induced leakage, but azide, fluoride and iodoacetate, which can prevent utilization of sugar (Lewis \& Phaff, 1965), significantly reduced glucose-induced leakage at $44^{\circ} \mathrm{C}$ (Table I). When yeast was heated at $44{ }^{\circ} \mathrm{C}$, suspended in water, cooled, and treated with glucose at $30^{\circ} \mathrm{C}$ the rate and extent of glucose-induced leakage was a function of the time of preincubation at $44^{\circ} \mathrm{C}$ (Table 2). Again, $\mathrm{Ca}^{2+}$ was found to have a protective effect. 
Table 2. Effect of glucose at $30^{\circ} \mathrm{C}$ on release of phosphate from Saccharomyces carlsbergensis $67-80$ preheated at $44{ }^{\circ} \mathrm{C}$ in aqueous suspension

Yeast ( $10 \mathrm{mg}$ dry wt $\mathrm{ml}$ ) was suspended in water at $44^{\circ} \mathrm{C}$. At appropriate times the sample was cooled to $30 \mathrm{C}$ and glucose $(5 \%, \mathrm{w} / \mathrm{v})$ was added. Phosphate release, reported as inorganic phosphorus $(/ \mathrm{g} \mathrm{ml})$, was measured after I h.

$\overbrace{0}^{\text {Time of pre-incubation at }}$ I0 $_{20}^{40} \frac{\mathrm{C} \text { in water (min) }}{30}$

Yeast at $30^{\circ} \mathrm{C}$ suspended in

Water
Glucose
Glucose $+\mathrm{Ca}^{2--}$
Lactose $(5 \%, \mathrm{w} / \mathrm{v})$
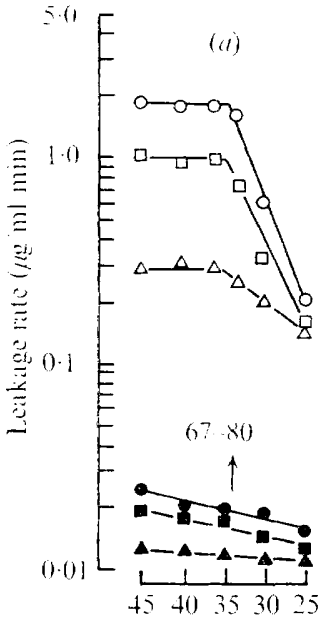

Phosphate $\left(\mathbf{P}_{\mathrm{i}}\right)$ release $(\mu \mathrm{g} / \mathrm{mI})$

$\begin{array}{rrrrrr}2.0 & 2.0 & 2.5 & 2.5 & 3.5 & 5.0 \\ 10.0 & 10.0 & 12.5 & 17.0 & 25.0 & 38.0 \\ 5.0 & 5.8 & 6.2 & 8.0 & 7.0 & 9.0 \\ 3.0 & 3.0 & 3.0 & 4.6 & 6.2 & 8.0\end{array}$

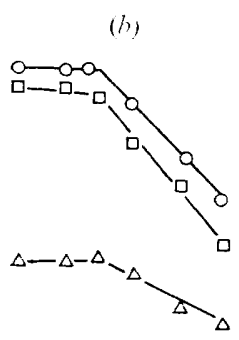

(c)
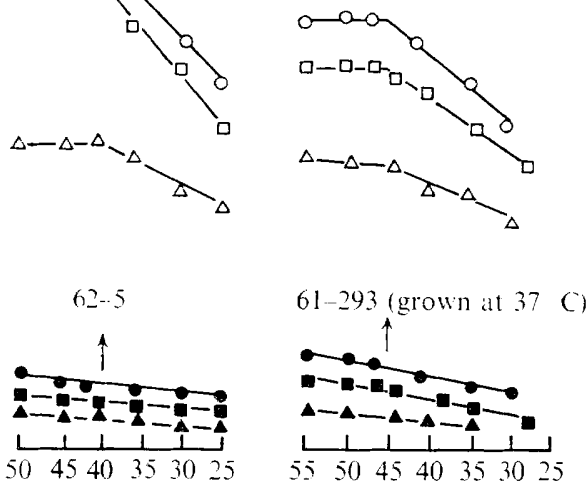

Temperature (1 K). (centigrade equivalent shown)

Fig. I. Initial rate of release of cell contents of three yeasts suspended at various temperatures in glucose solution (open symbols) or water (solid symbols). The $T_{\max }$ of each yeast is indicated by an arrow. $O, \boldsymbol{O}, \alpha$-Amino nitrogen; $\square, \mathbf{\square}$, phosphate $\left(\mathrm{P}_{\mathrm{i}}\right) ; \Delta, \mathbf{\Delta}, E_{260}$.

These data imply that heat stress alone is insufficient to cause extensive damage, as judged by leakage of yeast contents, but damage does occur and may become critical when utilizable sugar is provided during or subsequent to heat stress.

\section{Leakage of yeast contents}

In water suspension, leakage of contents from Saccharomyces carlsbergensis 67-80 followed temperature-dependent zero-order kinetics with no marked change in rate of leakage at or near $T_{\max }$. The rate of leakage was low and total leakage did not exceed $5 \%$ of the total hot-water extractable contents in the most severe treatment used (Fig. I $a$ ). In glucose solution the rate of leakage of contents increased with incubation temperature until it reached a maximum rate at or close to $T_{\max }$; above $T_{\max }$ the leakage rate remained constant (Fig. I a). Similarly, with Saccharomyces cerevisiae $62-5\left(T_{\max } 40^{\circ} \mathrm{C}\right)$ and Kluyveromyces fragilis $6 \mathrm{I}-293\left(T_{\max } 45^{\circ} \mathrm{C}\right)$ the maximum rate of leakage in each case was reached 


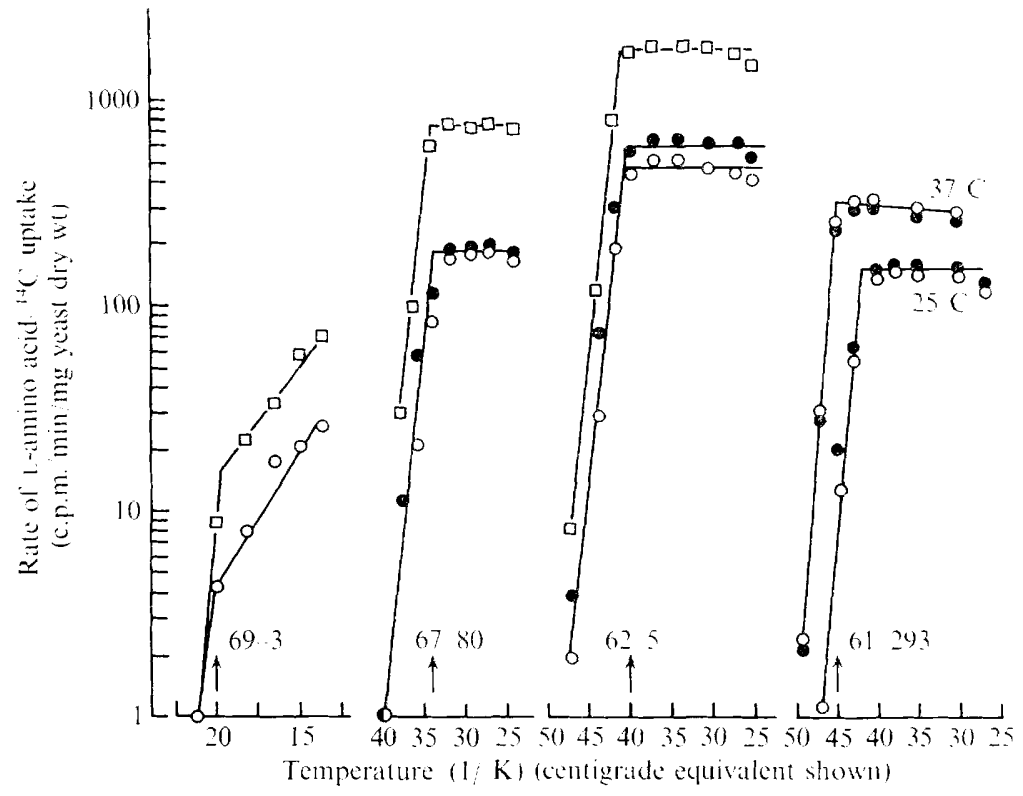

Fig. 2. Maximum rate of uniformly ${ }^{14} \mathrm{C}$-labelled $\mathrm{L}$-amino acid uptake by four yeasts suspended in glucose solution at various temperatures. $O, L-\left[{ }^{14} \mathrm{C}\right]$ Tyrosine; $\mathbf{O}, \mathrm{L}-\left[{ }^{14} \mathrm{C}\right]$ alanine; $\square, \mathrm{L}-\left[{ }^{14} \mathrm{C}\right] l y$ sine. Data points on the abscissa mean that no uptake could be measured. Kluyveromyces fragilis $6 \mathbf{I}-293$ was grown at 37 and $25^{\circ} \mathrm{C}$. The $T_{\text {max }}$ of each yeast is indicated by an arrow.

close to the $T_{\max }$ of the yeast tested (Fig. I $b, c$ ). When glucose-induced leakage was analysed in terms of the extent of leakage relative to incubation temperature, the amount of phosphate leakage was considerably greater and more temperature dependent above $T_{\max }$ than below it. In all three yeasts the marked change in leakage was close to the $T_{\max }$ of the yeast. The reason for this is clear; at temperatures close to and above $T_{\max }$ the ability was lost to resorb the intracellular components leaked in the presence of glucose, and ultimately (depending on temperature) extensive and irretrievable loss of yeast contents occurred. With yeast $6 \mathrm{I}-293\left(T_{\max } 45^{\circ} \mathrm{C}\right)$ there was extensive glucose-induced leakage several degrees below $T_{\max }$ if the yeast was grown at 25 rather than at $37{ }^{\circ} \mathrm{C}$. We have previously shown an effect of growth temperature on the response of yeast to heat stress and glucose (Lewis \& Kuiper, 1972).

\section{Amino-acid uptake}

Amino-acid uptake rates were slower above the $T_{\max }$ of a psychrophilic yeast than below it (Clinton, 1968 ) and these rates declined sharply above the $T_{\max }$ of Pseudomonas aeruginosa (Kay \& Gronlund, 1969). Net uptake of amino acids from the medium must require an intact and functioning cytoplasmic membrane and an available source of energy. Aminoacid uptake rates of our yeasts in the presence of glucose showed a clear temperature dependence (Fig. 2). Uptake rates declined slightly at or immediately below $T_{\text {max }}$, especially with yeasts $69-3$ and $6 \mathrm{I}-293$ grown at $25^{\circ} \mathrm{C}$; above the $T_{\max }$ the uptake rates of all yeasts were substantially slowed, and with yeast 69-3 no uptake could be measured. If the data of Fig. 2 were interpreted as two straight lines, an intersection close to $T_{\max }$ was achieved. Pre-incubation of cells in water suspension above $T_{\max }$ did not appreciably alter the aminoacid uptake rates as measured at the optimum temperature for growth. 


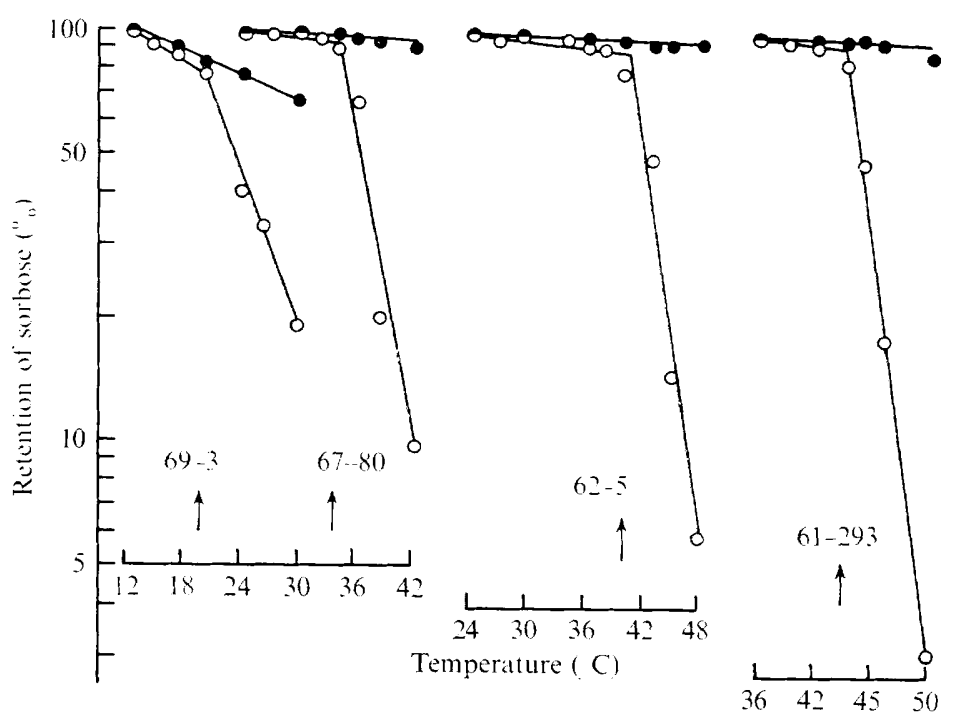

Fig. 3. Sorbose retention of four yeasts exposed for $\mathrm{I}$ h to glucose solution (open symbols) or water (solid symbols) at various temperatures. After incubation the cells were washed four times and loaded with sorbose at $25^{\circ} \mathrm{C}$ (or at $13{ }^{\circ} \mathrm{C}$ in the case of Leucospiridium stokesii 69-3) by equilibration with a $5 \%(\mathrm{w} / \mathrm{v})$ solution of sorbose for $\mathrm{I} h$. The cells were then washed with saline at 0 "C and the sorbose content of the hot water extracts determined. Sorbose retention is recorded as a percentage of sorbose retained by cells incubated throughout in water or glucose solution at $25 \mathrm{C}$ (or at $13^{\circ} \mathrm{C}$ in the case of $L$. stokesii $69-3$ ). The $T_{\max }$ of each yeast is indicated by an arrow.

\section{Table 3. ATPase activity and cell death of yeasts exposed to glucose solution at various temperatures}

Yeasts were suspended in water or glucose solution $(5 \%, \mathrm{w} / \mathrm{v})$ for $40 \mathrm{~min}$ at the temperatures indicated, cooled to $30{ }^{\circ} \mathrm{C}$ (or $18{ }^{\circ} \mathrm{C}$ for yeast 69-3) and washed four times in distilled water. $\mathrm{Mg}^{2+}$-ATPase activity is expressed as phosphorus $\left(\mathrm{P}_{\mathrm{i}}\right), \mu \mathrm{mol} / \mathrm{mg}$ dry wt of yeast $/ \mathrm{h}$, at $\mathrm{pH} 8 \cdot 0$ with ATP as substrate. Dead cells were determined by methylene blue staining and are reported in parentheses to the nearest $5 \%$.

Yeast suspended in

$69-3\left(\mathrm{~T}_{\max } 20 \mathrm{C}\right)$

Water

Glucose

$67-8\left(\mathrm{~T}_{\ln i \mathrm{x}} 34^{\circ} \mathrm{C}\right)$

Water

Glucose

$6 \mathrm{I}-293\left(T_{\text {max }} 45^{\circ} \mathrm{C}\right.$ grown at $\left.37^{\circ} \mathrm{C}\right)$

Water

Glucose
Incubation temperature $\left({ }^{\circ} \mathrm{C}\right)$

\begin{tabular}{|c|c|c|c|c|c|c|c|c|c|}
\hline \multicolumn{10}{|c|}{ Incubation temperature $\left({ }^{\circ} \mathrm{C}\right)$} \\
\hline I 4 & I 8 & 22 & 25 & 30 & 35 & 40 & 45 & 50 & 55 \\
\hline \multicolumn{10}{|c|}{ ATPase activity and cell death } \\
\hline 0.0 & 0.0 & $0 \cdot 0$ & 0.0 & 一 & - & - & - & - & 一 \\
\hline (IO) & (IO) & (20) & (20) & 一 & - & - & - & - & 一 \\
\hline 0.0 & 0.0 & 0.25 & 0.38 & - & 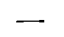 & $\ldots$ & - & - & - \\
\hline (10) & (IO) & (35) & $(80)$ & 一 & - & - & - & - & - \\
\hline \multirow[t]{2}{*}{-} & 一 & - & 0.0 & 0.0 & 0.0 & 0.0 & - & 0.10 & - \\
\hline & & & (5) & (5) & (5) & (5) & - & (10) & - \\
\hline \multirow[t]{2}{*}{-} & - & - & 0.0 & 0.0 & 0.72 & 0.96 & - & 0.88 & 一 \\
\hline & & & (5) & (5) & (40) & (90) & - & $(100)$ & - \\
\hline- & $\cdots$ & - & - & $\begin{array}{c}0.0 \\
(0)\end{array}$ & $\begin{array}{c}0.0 \\
(0)\end{array}$ & 0.0 & - & $\begin{array}{l}0.12 \\
(10)\end{array}$ & 0.48 \\
\hline & & & & & & & & & \\
\hline - & - & - & - & (5) & (5) & $(15)$ & - & $\begin{array}{l}0.00 \\
(80)\end{array}$ & (100) \\
\hline
\end{tabular}




\section{Sorbose retention}

The intracellular water of yeast can equilibrate with a sorbose solution. If the membrane is intact the sorbose taken into the yeasts is retained when the extracellular sorbose is removed by washing with saline at $0^{\circ} \mathrm{C}$ or with uranyl nitrate solution (Cirillo et al. 1964 ; Cirillo \& Wilkins, I964). Yeast exposed to glucose solution below $T_{\max }$ then equilibrated with sorbose solution retained sorbose after washing, but exposure to glucose solution at temperatures above $T_{\max }$, before sorbose treatment, considerably reduced the ability of the yeasts to retain sorbose (Fig. 3). In water suspension, high temperature had little effect on sorbose retention. If the data were interpreted as two straight lines, an intersection close to the $T_{\max }$ of each yeast was realized.

\section{ATPase activity and cell death}

When the yeast cytoplasmic membrane is ruptured, an $\mathrm{Mg}^{2+}$-ATPase activity can be measured in the washed cells (Cirillo et al. I964; Ohwaki \& Lewis, I 97I). Such activity was found in yeasts exposed to glucose above the $T_{\max }$ but not below it (Table 3 ). This treatment also caused cell death. Suspension of yeast above $T_{\max }$ in water caused neither cell death nor exposure of ATPase activity.

\section{DTSEUSSTUN}

Yeasts suspended in water gave little evidence of thermal injury in our test systems. Injury readily occurred when glucose was present during heating or was added after heat stress. This effect was unique to utilizable sugars and may be related to sugar transport (Lewis \& Phaff, I965) since materials that inhibit sugar uptake decreased leakage (Table I). Leakage of yeast contents can be induced by glucose at temperatures below $T_{\max }$; the rate of leakage is a function of temperature and the released materials (except u.v.-absorbing substances) are readily resorbed (Lewis \& Phaff, 1964). Above the $T_{\max }$, however, the leakage achieved a temperature-independent maximum rate and ability to resorb the released material was lost. Though we cannot differentiate between glucose effects and temperature effects, the net result is a substantial irreversible loss of yeast contents, and ultimately cell death.

We have previously shown glucose-induced leakage of yeast contents to be an effect of glucose at the cytoplasmic membrane (Lewis \& Stephanopoulos, I967). In this work the non-specific nature of the leakage and the partial protective effect of $\mathrm{Ca}^{2+}$ provided presumptive evidence of membrane damage. The amino-acid uptake data are not necessarily evidence of a ruptured membrane, merely an ineffective one; thus the specific amino-acid uptake sites could be heat sensitive. Direct evidence for a ruptured membrane is provided by the sorbose retention and ATPase data. A concentration gradient of sorbose cannot be established or maintained by yeast heated above $T_{\max }$ in glucose solution because the intracellular sorbose can equilibrate with saline at $0^{\circ} \mathrm{C}$ or with uranyl nitrate solution through those parts of the membrane that have lost integrity. Cells heated above the $T_{\max }$ in water suspension must retain an intact membrane because the ability of the cells to retain sorbose is unaffected by the heat treatment. Similarly, membrane-damaged yeast reveals ATPase activity because the substrate ATP is permitted access to the intracellular particle-bound enzyme. This characteristic is seen in yeast heated above $T_{\max }$ in glucose solution but not in yeast heated in water suspension. Yeast can readily survive heat stress in water suspension and can resist or recover from the effects of glucose subsequently applied at a temperature below $T_{\text {max }}$. Our primary conclusion is that no growth of our yeasts can occur above their 
$T_{\max }$ because the utilizable sugar of the growth medium can damage the cytoplasmic membrane.

The optimum growth temperature of yeasts is usually several degrees below $T_{\max }$. The values we measured for sorbose retention and amino-acid uptake rate are lower, close to but below the $T_{\max }$, than they are at the optimum temperature. This may indicate that, slightly below $T_{\max }$, heat and glucose can adversely affect yeast performance. At growth temperature above the optimum but below $T_{\max }$, Van Uden (197I) has identified logarithmic death coincident with logarithmic growth. His observation and ours may well be related.

Though the same general pattern of results was achieved with all four yeasts tested, our data were most readily gathered and interpreted for yeasts $67-80$ and $62-5$. The psychrophile 69-3 and the high-temperature yeast $69-293$ grown at $25^{\circ} \mathrm{C}$ showed a substantial decline in amino-acid uptake rates several degrees below $T_{\max }$, and the psychrophile leaked sorbose below its $T_{\max }$. It is possible that the $T_{\max }$ values we determined for these two yeasts depended on a protective effect of growth-medium constituents that were not present in our glucose test system. Alternatively, the trends shown by yeasts $67-80$ and $62-5$ may be exaggerated in the yeast with extremes of $T_{\max }$, especially the psychrophile. It may be significant that previous leakage data related to $T_{\max }$ were measured with a psychrophile (Nash \& Sinclair, 1968) and a correlation of death with $T_{\max }$ was realized only with yeasts with a particularly high $T_{\max }$ (Van Uden, Abranches \& Cabeca-Silva, I968).

Tests for thermal injury to yeasts have previously been conducted with resting yeast suspended in water or buffer, but growth characteristics of yeasts are usually measured in media that contain utilizable sugar. There is an evident dichotomy here that has previously prevented identification of a physiological event that correlates closely with $T_{\max }$. Our data point to damage to the cytoplasmic membrane in the presence of utilizable sugar as one cause of no growth above $T_{\max }$ of our yeasts, and we believe it to be a primary contributing factor, but other properties may show an equally close correlation with $T_{\max }$ if measured in actively metabolizing yeasts.

A. N. H. gratefully acknowledges receipt of a United States Public Health Service Traineeship (grant no. AH oo663) during the course of this work.

\section{REFERENCES}

Belly, R. T. \& Brock, T. D. (1972). Cellular stability of a thermophilic, acidophilic mycoplasma. Journal of General Microbiology 73, 465-469.

Brock, T. D. (1967). Life at high temperatuies. Science, New York 158, 1012-1019.

Cirillo, V. P., Harsch, M. \& Lampen, J. O. (1964). Action of the polyene antibiotics filipin, nystatin and $n$-acetyl candidin on the yeast cell membrane. Journal of General Microbiology 35, 249-259.

Cirillo, V.P. \& Wilkins, P. O. (1964). Use of uranyl ion in membrane transport studies. Journal of Bacteriology 87, 232-233.

Clinton, R. H. (1968). Effects of temperature on the uptake of glutamic acid and lysine in a psychrophilic yeast. Antonie van Leeuwenhoek 34, 99-105.

Diamond, R. J. \& Rose, A. H. (1970). Osmotic properties of spheroplasts from Saccharomyces cerevisiae grown at different temperatures. Journal of Bacteriology 102, 3I 1-319.

Dische, Z. \& Devi, A. (1960). Colorimetric method for the determination of ketohexoses in the presence of aldoses, ketoheptoses and ketopentoses. Biochimica et biophysica acta 39, 140-144.

Evison, L. M. \& Rose, A. H. (I965). A comparative study on the biochemical basis of the maximum temperatures for growth for three psychrophilic microorganisms. Journal of General Microbiology 40, $349-364$.

Fiske, C. H. \& SubbaRow, Y. (I925). Methods for analysis of phosphorylated intermediates. In Manometric Techniques and Tissue Culture. Edited by W. W. Umbreit, R. H. Burris and J. F. Stauffer. Minneapolis, Minnesota, U.S.A. (I 954): Burgess Publishing. 
Grant, D. W., Sinclair, N. A. \& Nash, C. H. ( I968). Temperature-sensitive glucose fermentation in the obligately psychrophilic yeast Candida gelida. Canadian Journal of Microbiology r4, I I05-I I 10.

Hagen, P. O. \& Rose, A. H. (1962). Studies on the biochemical basis of the low maximum temperature in a psychrophilic Cryptococcus. Journal of General Microbiology 27, 89-99.

INDGE, K. J. (I968). Metabolic lysis of yeast protoplasts. Journal of General Microbiology 51, 433-440.

JONES, R. C. \& Hough, J. S. (I970). The effect of temperature on the metabolism of baker's yeast growing in continuous culture. Journal of General Microbiology 60, 107-11 6.

Kay, W. W. \& Gronlund, A. F. (I969). Amino acid transport in Pseudomonas aeruginosa. Journal of Bacteriology 97, 273-28I.

LEE, T. C. \& LEwIS, M. J. (I968). Release of u.v.-absorbing substances by fermenting brewer's yeast. Journal of Food Science 33, I24-129.

LEwis, M. J. \& KuiPER, H. A. (I972). Effect of growth temperature and glucose on thermal injury of Saccharomyces carlsbergensis. Journal of the Institute of Brewing 78, 465-470.

Lewis, M. J. \& PhafF, H. J. (1964). Release of nitrogenous substances by brewer's yeast. III. Shcck excretion of amino acids. Journal of Bacteriology 87, I389-I 396.

Lewis, M. J. \& PhafF, H. J. (I965). Release of nitrogenous substances by brewer's yeast. IV. Energetics in shock excretion. Journal of Bacteriology 89, 960-966.

Lewis, J. J. \& Stephanopoulos, D. (1967). Glucose-induced release of amino acids from Saccharomyces carlsbergensis by action on the cytoplasmic membrane. Journal of Bacteriology 93, 976-984 .

Moore, S. \& SteIn, W. H. (1954). A modified ninhydrin reagent for the photometric determination of amino acids and related compounds. Journal of Biological Chemistry 21 I, 907-913.

NASH, C. H. \& Grant, D. W. ( I969). Thermal stability of ribosomes from a psychrophilic and mesophilic yeast. Canadian Journal of Microbiology 15 , I I I 6-1 1 I 8.

Nash, C. H., Grant, D. W. \& Sinclair, N. A. (1969). Thermolability of protein synthesis in a cell-free system from the obligately psychrophilic yeast Candida gelida. Canadian Journal of Microbiology $\mathbf{5}$, $339-343$.

Nash, C. H. \& Sinclair, N. A. (I968). Thermal injury and death in an obligately psychrophilic yeast, Candida nivalis. Canadian Journal of Microbiology 14, 69 I-697.

OHwaki, K. \& Lewis, M. J. (197I). Adenosine triphosphatase of Saccharomyces carlsbergensis. Journal of the Institute of Brewing 77, 352-357.

RAY, P. H. \& Brock, T. D. (I97I). Thermal lysis of bacterial membranes and its prevention by polyamines. Journal of General Microbiology 66, $133-135$.

Sinclair, N. A. \& Stokes, J. L. (1965). Obligately psychrophilic yeasts from the polar region. Canadian Journal of Microbiology Ir, 259-269.

StOKES, J. L. (197I). Influence of temperature on the growth and metabolism of yeast. In The Yeasts, vol. 2, pp. I 19-134. Edited by A. H. Rose and J. S. Harrison. London and New York: Academic Press.

VAN Uden, N. (1971). Kinetics and energetics of yeast growth. In The Yeasts, vol. 2, pp. 75-118. Edited by A. H. Rose and J. S. Harrison. London and New York: Academic Press.

Van Uden, N., Abranches, P. \& Cabeca-Silva, C. (1968). Temperature functions of thermal death in yeast and their relation to the maximum temperature for growth. Aichiv fiir Mikrobiologie 6r, 381-393. 